Evaluating the relation between pruritus, serum IgE levels and severity of clinical manifestations in atopic dermatitis patients*

\title{
Avaliação da relação do prurido e níveis sangüíneos de IgE com a gravidade do quadro clínico em pacientes com dermatite atópica*
}

\author{
Magda Blessmann Weber ${ }^{1}$ \\ Nicolle Gollo Mazzotti ${ }^{4}$
}

\author{
Vanessa Petry ${ }^{2}$ \\ Tania Ferreira Cestari ${ }^{5}$
}

Luciana Weis ${ }^{3}$

\begin{abstract}
BACKGRound - Atopic dermatitis patients often have high serum immunoglubulin $\mathrm{E}(\mathrm{lgE})$ levels and pruritus is a major symptom of the disorder. OBJECTIVE - To describe the characteristics of pruritus in atopic dermatitis (AD) patients and to correlate severity of eczema with plasma IgE levels Methods - Patients with atopic dermatitis seen at the Dermatology Service of Hospital de Clínicas de Porto Alegre and at the Dermatology and Pediatrics Service of Universidade Luterana do Brasil filled out a questionnaire on AD symptoms and had their blood collected for serum IgE levels. Severity of dermatitis was assessed according to criteria adopted by Rajka et al. Data were analyzed by SPSS program.

REsults: Eighty-nine patients completed the study. The mean age was $9.6 \pm 9$ years and $51 \%$ were female. The relation between frequency of pruritus and severity of dermatitis was significant $(p=0.003)$. Forty-five percent of patients with mild atopic dermatitis presented pruritus every day, $90.9 \%$ of severe patients showed daily symptoms, and only $4.5 \%$ remained symptom-free for more than seven days. The median serum IgE level was $347 \mathrm{UI} / \mathrm{ml}$. The median serum IgE levels for mild, moderate and severe cases was $279 \mathrm{UI} / \mathrm{ml}, 347 \mathrm{UI} / \mathrm{ml}$ and $952 \mathrm{UI} / \mathrm{ml}$, respectively $(p=0.699)$. Females showed significantly lower serum lgE levels when compared to males (212 Ul/ml vs. $2067 \mathrm{UI} / \mathrm{ml}, \mathrm{p}=0.004)$.

ConcLusions - Although lgE levels were higher in severe patients, this study did not demonstrate a trend toward greater levels in patients with severe eczema as compared with mild eczema. Males have significantly higher serum IgE levels than females.

Keywords: Dermatitis, atopic; Immunoglobulin E; Pruritus
\end{abstract}

\begin{abstract}
Resumo: Fundamentos - Pacientes portadores de dermatite atópica apresentam freqüentemente níveis séricos el evados de lgE, e o prurido é uma das manifestaçōes cardinais da doença.

OBjETIVOS - Descrever as características do prurido nos pacientes com dermatite atópica (DA) e correlacionar a gravidade do eczema com os níveis plasmáticos de imunoglobulina $\mathrm{E}(\mathrm{lgE})$.

Métodos - Os pacientes com dermatite atópica atendidos no Serviço de Dermatologia do Hospital deClínicas de Porto Alegreenos Serviçcos de Pediatria e Dermatologia da Universidade Luterana do Brasil responderam a um questionário sobre sintomas da dermatite atópica edeles foi coletado sangue para dosagem da IgE sérica. A gravidade da dermatose foi calculada conforme critérios sugeridos por Rajka et al. Os dados foram analisados no programa SPSS.

RESULTADOS - Oitenta enove pacientes completaram o estudo. A média de idade foi de $9,6 \pm 9$ anos, e 51\%dos pacientes eram do sexo feminino. Quando analisada a frequêencia de prurido de acordo com a gravidade do quadro clínico, foi encontrada uma relação significativa $(p=0,003)$. Os pacientes com quadro leve de dermatite atópica tinham coceira diária em 45\% dos casos; aqueles com quadro gravetinham 90,9\% de sintomas diários; eapenas 4,5\% tinham mais de sete dias de intervalo entre os episódios de coceira. A mediana dos níveis de lgE sérica foi de 347Ul|ml. As medianas da IgE sérica nos pacientes com eczema leve, moderado e grave foram $279 \mathrm{Ul} / \mathrm{ml}, 347 \mathrm{Ul} / \mathrm{ml}$ e $952 \mathrm{Ul} / \mathrm{ml}$, respectivamente $(p=0,699)$. Pacientes do sexo feminino apre sentaram níveis de lgE menores do que os do sexo masculino (212Ul/ml and 2067U//ml, p=0,004).

Conclusão - Pacientes com quadros graves de dermatite atópica apresentam prurido mais freqüente do que aqueles com manifestações mais leves. $\mathrm{Na}$ avaliação dos níveis séricos de lgE em relação à gravidade da DA, apesar de os valores serem mais altos nos pacientes mais graves, não se encontrou rela ação estatística significativa. Pacientes do sexo mascul ino têm níveis séricos de lgE significativamente mais altos do que os do sexo feminino. A frequêencia do prurido está relacionada com a gravidade da dermatite atópica.

Palavras-chave: Dermatite atópica; Imunogl obulina E; Prurido
\end{abstract}

\section{INTRODUCTION}

Atopic dermatitis (AD) is a very common disease, mainly in childhood, which affects from 10 to $20 \%$ of children in developed countries. ${ }^{1-3}$ Forty to sixty percent of patients with this dermatosis present associated respiratory allergic manifestations. ${ }^{2,48}$

The etiopathogenesis of AD has not been com-

\footnotetext{
Received on August 11, 2004.

Approved by the Consultive Council and accepted for publication on May 24, 2005.

"Work done at Serviço de Dermatologia - Hospital de Clínicas de Porto Alegre - Universidade Federal do Rio Grande do Sul - UFRGS (RS) - Brazil.

Adjunct Professor, Master's degree in Dermatology from the Universidade Luterana do Brasil - Ulbra (RS).

Medical Doctor graduated from the Universidade Luterana do Brasil - Ulbra (RS).

Medical Doctor graduated from the Universidade Luterana do Brasil - Ulbra (RS).

Medical Student at Universidade Federal do Rio Grande do Sul - UFRGS (RS).

Adjunct Professor, Ph.D. in Dermatology from the Universidade Federal do Rio Grande do Sul - UFRGS (RS).

C 2005 by Anais Brasileiros de Dermatologia
} 
pletely clarified, and it is considered a multifactorial disease, with intrinsic and extrinsic factors involved. As to humoral immunity, the main laboratory finding is increased total serum IgE levels in $70-80 \%$ of cases. Some authors correlated total serum IgE levels with severity of clinical manifestations; however it has not been defined yet. ${ }^{9-13}$

Allergic or atopic individuals produce IgE after contact with allergens even at low concentrations. This response occurs in the site where the allergen penetrates the body (mucosal surfaces, skin and/or local lymph nodes). The produced IgE first sensitizes local mast cells, causing immediate allergic reactions (histamine release); the exceeding IgE enters circulation and binds to receptors both in circulating basophils and mast cells fixed in tissues throughout the body, and thus triggering systemic reactions. ${ }^{14,15}$

Pruritus is the main symptom in all $A D$ patients, in any phase of the disease, and the act of scratching leads to most skin lesions. ${ }^{16,17}$ In a study with 100 Chinese patients with atopic dermatitis, Yosipovitch et al. demonstrated that most of them suffered form pruritus every day, primarily in the cervical region and in joints, and pruritus was at least twice more intense than that related to insect stings. ${ }^{18}$

Different methods have been proposed to assess severity of $A D . .^{19,20}$ Past or family history, age at onset of eczema and pruritus intensity are some factors mentioned as extremely important to quantify the clinical manifestation of the disease. ${ }^{21}$

The most used method to verify intensity of the clinical picture of atopic patients was proposed by Rajka et al., ${ }^{20}$ and it takes into account the extension of body surface with lesions, the natural history of the disease and intensity of pruritus.

To understand and manage the situations that trigger and aggravate pruritus in atopic patients may lead to significant improvement of clinical manifestations and less severe cases. Thus, this study aims to evaluate the relation between pruritus and IgE levels in $A D$ patients, as well as to correlate these levels with severity of $A D$ symptoms.

\section{METHODS}

A cross-sectional analytical study was carried out and the sample comprised AD patients seen at the outpatient's clinics of the Dermatology Service of the Hospital de Clínicas de Porto Alegre and at the Dermatology and Pediatrics Services of the Universidade Luterana do Brasil. The sample size to detect difference in IgE levels and moderate intensity of the disease (effect size of 1 , that is, one standard deviation) should have a minimum of 17 patients in each severity level. If we estimate that there are fewer severe patients $(20 \%)$, we would need approximately 86 patients.

The inclusion criteria adopted were clinical manifestations of $A D$ when enrolling in the study and to agree to take part in it. The following patients were excluded: individuals presenting pruritic dermatoses different from $A D$, patients on medications that cause pruritus as side effect, and suffering any disease that induces higher blood IgE levels, except for asthma or allergic rhinitis, which were analyzed during the study.

Data were collected based on a questionnaire applied during the routine visit. Parents of illiterate children were asked to help them filling in the questionnaire, which comprised questions regarding symptoms and activities of daily life of patients. The questions were adjusted from the questionnaire validated by Yosipovitch et al., in 2002 , describing pruritus in atopic dermatitis patients. ${ }^{18}$ The physical examination to assess severity of disease was performed by a dermatologist, according to the criteria established by Rajka and Langeland ${ }^{20}$ who divided AD into mild, moderate and severe disease.

The serum IgE results of patients who had been recently submitted to examination (during the last atopic dermatitis exacerbation) were retrieved from the medical record. Patients who had no IgE results were asked to have the test performed during the enrollment visit.

This study was approved by the Research Ethics Committee of the Hospital de Clínicas de Porto Alegre in March 2003, as to its scientific and methodology (protocol number 03-17) and approved by the Ethics Committee of Ulbra, in May 2003.

The SPSS program was applied to analyze data, and we used frequencies, medians, 25 percentile (p25) and 75 percentile (p75). In order to compare IgE level with severity of $A D$, the Kruskal-Wallis test was used. Mann-Whitney and chi-squared tests were used for analysis. The significance level was $\alpha=0,05$.

\section{RESULTS}

From April 2003 to January 2004, 89 atopic dermatitis patients were examined and had the following demographic characteristics (Table 1).

Concerning frequency of pruritus, most patients had symptoms every day (71.90\%); $15.7 \%$ complained of itching during some days per week and $12.40 \%$ presented this symptom with at least a seven-day interval. Evaluating frequency of pruritus and severity of manifestations, a significant relation ( $p=0.003$; chi-squared test) was observed. Forty-five percent of patients with mild $A D$ presented itching every day, 20\% every week and 35\% had less than once a week. As to patients with a moderate condition, $74.5 \%$ had daily symptoms, $19.1 \%$ weekly symptoms, and only $6.4 \%$ presented an interval longer than seven days. On the other hand, in seven severe individuals, $90.9 \%$ presented symptoms every day, and only $4.5 \%$ reported an interval longer than seven days between itching episodes.

The median IgE levels of the patients studied were $347 \mathrm{UI} / \mathrm{ml}$; and the 25 and 75 percentiles corresponded to $98 \mathrm{UI} / \mathrm{ml}$ and $3.222 .50 \mathrm{UI} / \mathrm{ml}$, respectively. In $24 \%$ of patients IgE levels were lower than $100 \mathrm{UI} / \mathrm{ml}$ (normal); in $31.5 \%$ they ranged from 100 to $500 \mathrm{UI} / \mathrm{ml}$; in $21.3 \%$, from 501 to $4000 \mathrm{UI} / \mathrm{ml}$; and in $22.5 \%$ they were greater than $4001 \mathrm{UI} / \mathrm{ml}$. 
TABLE 1: Characteristics of AD patient population

\begin{tabular}{|c|c|}
\hline Mean age (years) & 9.60 ( \pm 9 anos) \\
\hline $\begin{array}{l}\text { Female } \\
\text { Male }\end{array}$ & $\begin{array}{l}51.70 \% \\
48.30 \%\end{array}$ \\
\hline $\begin{array}{l}\text { Association with other atopic manifestations } \\
\text { Only atopic dermatitis } \\
\text { Atopic dermatitis and asthma } \\
\text { Atopic dermatitis and allergic rhinitis } \\
\text { Atopic dermatitis, asthma and allergic rhinitis }\end{array}$ & $\begin{array}{l}33.70 \% \\
42.70 \% \\
43.80 \% \\
25.84 \%\end{array}$ \\
\hline $\begin{array}{l}\text { Severity of clinical manifestations } \\
\text { Mild } \\
\text { Moderated } \\
\text { Severe }\end{array}$ & $\begin{array}{l}22.70 \% \\
52.30 \% \\
25 \%\end{array}$ \\
\hline
\end{tabular}

Correlating clinical severity of AD with IgE levels, in mild patients we found a median of $27901 / \mathrm{ml}$ ( $p 25=103 \mathrm{Ul} / \mathrm{ml}$ and $\mathrm{p} 75=2431 \mathrm{Ul} / \mathrm{ml}$ ); in patients with moderate manifestations, a median of $347 \mathrm{UI} / \mathrm{ml}$ $(\mathrm{p} 25=56 \mathrm{UI} / \mathrm{ml}$ and $\mathrm{p} 75=2267 \mathrm{Ul} / \mathrm{ml})$; and in severely affected individuals, a median of $952 \mathrm{UI} / \mathrm{ml}$ $(p 25=135 \mathrm{Ul} / \mathrm{ml}$ and $p 75=4.085 \mathrm{Ul} / \mathrm{ml})(p=0.699$; Mann-Whitney test) (Graph 1).

The median IgE found in females was $1440.89 \mathrm{UI} / \mathrm{ml}(\mathrm{p} 25=62 \mathrm{UI} / \mathrm{ml}$ and $p 75=758 \mathrm{Ul} / \mathrm{ml}$ ), whereas in males it was $2067 \mathrm{Ul} / \mathrm{ml}$ (p25 $=155 \mathrm{Ul} / \mathrm{ml}$ and $\mathrm{p} 75=4.190 \mathrm{Ul} / \mathrm{ml}$ ) (Graph 2), and the IgE level difference was statistically significant $(p=0.004)$.

The patients reporting daily pruritus had a median $\mathrm{IgE}$ of $388.50 \mathrm{UI} / \mathrm{ml} \quad(\mathrm{p} 25=143.50 \mathrm{UI} / \mathrm{ml}$ and p $75=3435.25 \mathrm{Ul} / \mathrm{ml}$ ), whereas those with this complaint every week had $365 \mathrm{UI} / \mathrm{ml}$ (p25 $=90.50 \mathrm{UI} / \mathrm{ml}$ and $\mathrm{p} 75=3709.50 \mathrm{Ul} / \mathrm{ml}$ ), and for patients suffering at intervals longer than one week it was $86 \mathrm{UI} / \mathrm{ml}(\mathrm{p} 25=20 \mathrm{UI} / \mathrm{ml}$ and $\mathrm{p} 75=935 \mathrm{Ul} / \mathrm{ml})(\mathrm{p}=0.129$; chi-squared test).

Only $33.7 \%$ of patients presented an isolated manifestation of $A D ; 42.7 \%$ of sample had associated bronchial asthma and $43.8 \%$ presented allergic rhinitis.

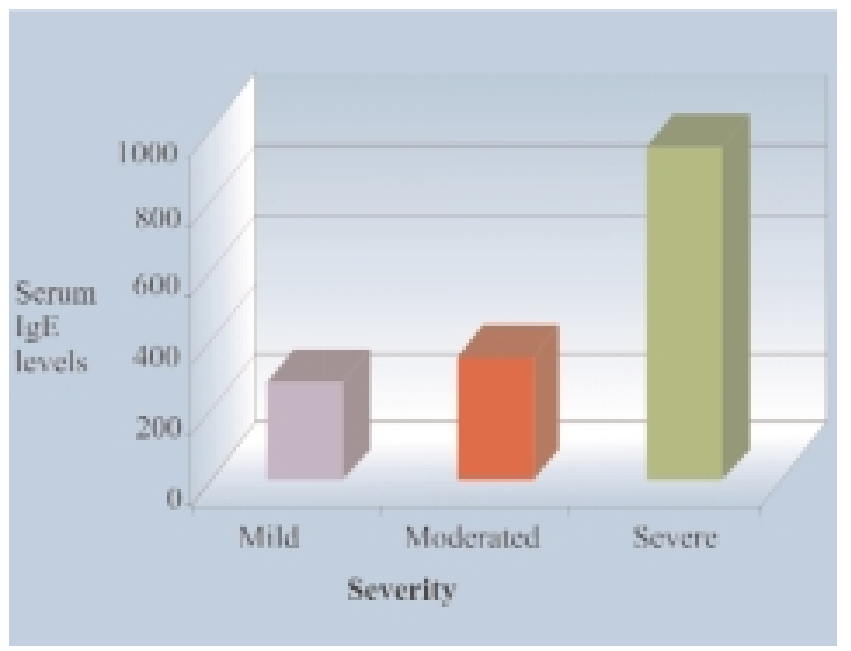

GRAPH 1: Severity of clinical manifestations according to serum IgE levels
Many patients (25.8\%) presented asthma and allergic rhinitis associated with $A D$.

\section{DISCUSSION}

$A D$ is a disease that may cause physical and psychological suffering to affected individuals. Its high incidence shows the need to better understand its etiological mechanism.

Asthma and rhinitis are conditions usually associated with $A D$ and are observed in $20-60 \%$ of patients. ${ }^{10-14}$ In the present sample, an association with asthma or rhinitis was found in $66.3 \%$ of patients, and the percentage was slightly higher than that described in the literature.

Pruritus is a predominant symptom in $A D$ patients, and the main cause of suffering of patients. ${ }^{15-18}$ Although most patients of this study (74.2\%) presented pruritus every day, this value was lower than that reported by Yosipovitch et al., ${ }^{18}$ who demonstrated that $87 \%$ of their sample presented daily symptoms.

In this study, the relation between severity of clinical manifestations and pruritus was as follows: $45 \%$ of patients with mild, $74.5 \%$ with moderate and $90.9 \%$

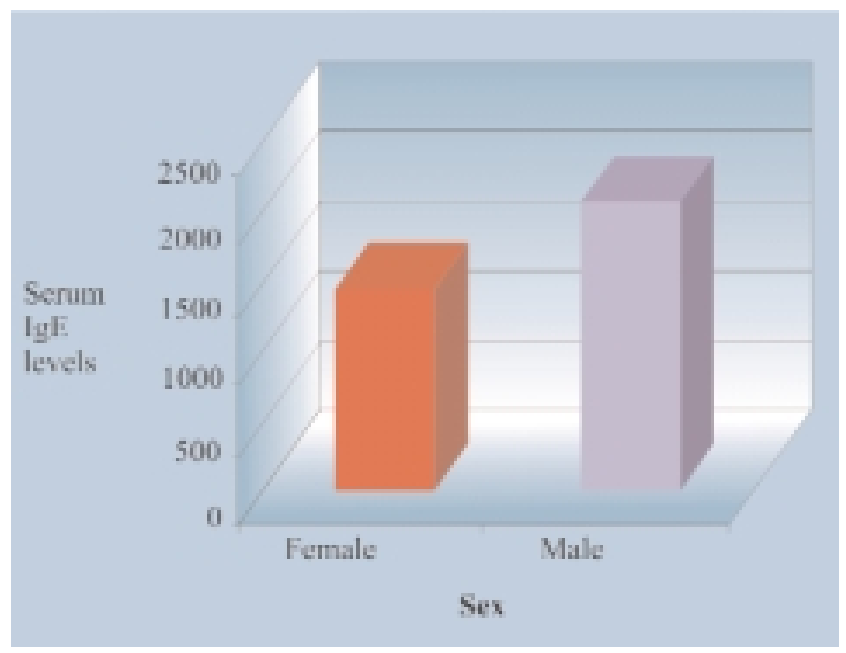

GRAPH 2: IgE levels according to sex 
with severe manifestations experienced itching every day. These findings indicated that patients with more severe $A D$ were also more symptomatic as to pruritus. This may be related to the fact that pruritus causes and maintains eczematous lesions in AD. In most cases, patients with more pruritus are those with larger lesions and consequently classified as more severe.

There is evidence that total serum IgE levels are increased in $A D$ patients..$^{4 \cdot 6}$ However, it is difficult to define normal levels, since IgE levels fluctuate in serum, likewise other immunoglobulins.

Several reports in the literature state that IgE would tend to present higher levels in patients with more severe allergy. ${ }^{3,5,6,19,21}$ In this study, these data were not significant $(p=0.699)$, unlike findings of previous works. ${ }^{5,6,19,21}$ Nevertheless, maybe there was no significant difference due to a high incidence of severe patients.

A significant relation was found in frequency of pruritus and severity of $A D$, and over $90 \%$ of severe patients presented pruritus every day. These findings are in accordance with the literature, confirming pruritus as an important symptom in atopic patients. ${ }^{18}$

The mean IgE level found in males was significantly higher than that of females $(p=0.001)$. This agrees with the findings reported by Spalding et al.,

\section{REFERENCES}

1. Kay J, Gawkrodger DJ, Mortimer MJ, Jaron AG. The prevalence of childhood atopic eczema in a general population. J Am Acad Dermatol.1994; 30: 35-9.

2. Hanifin JM, Cooper KD, Ho VC, Kang S, Krafchik BR, Margolis DJ, et al. Guidelines of Care for Atopic Dermatitis. J Am Acad Dermatol. 1992; 26: 485-8.

3. Eichenfield LF, Hanifin JM, Beck LA, Lemanske RF, Sampson HA, Weiss ST. Atopic dermatitis and asthma: parallels in the evalution of treatment. Pediatrics. 2003; 111:608-16.

4. Sampaio SAP, Rivitti EA. Dermatologia. 2a ed. São Paulo: Artes Médicas; 2001. p. 149-59.

5. Beltrani VS, Boguneiwicz M. Atopic dermatitis. Dermatol Online J. 2003; 9:1.

6. Ruzicha T. Atopic Eczema Between Rationality and Irrationality. Arch Dermatol. 1998. 134:1462-9.

7. Etter L, Myers SA. Pruritus in systemic disease: mechanisms and management. Dermatol Clin. 2002; 20:3.

8. Koblenzer CS. Itching and the atopic skin. J Allergy Clin Immunolog. 1999; 104: S109-13.

9. Leung DYM, Soter NA. Cellular and immunologic mechanisms in atopic dermatitis. J Am Acad Dermatol 2001;44:S1-12.

10. Hanifin JM, Chan S. Biochemical and immunologic mechanisms in atopic dermatitis: New targets for emerging therapies. J Am Acad Dermatol. 1999; 41:72-7.

11. Wuthrich B, Schmid-Grendelmeier P. The atopic eczema/dermatitis syndrome. Epidemiology, natural course, and immunology of the IgE-associated ("extrinsic") and the nonallergic ("intrinsic") AEDS. J Investig Allergol Clin Immunol. 2003;13:1-5.

12. Stingl G. Ige-mediated, Fc?RI-dependent allergen presentention: A pathogenetic factor in atopic dermatitis? J Am Acad Dermatol. 2001; 45:S1.

13. Laske N, Niggermann B. Does the severuty of atopic who observed a mean of $78.5 \mathrm{UI} / \mathrm{ml}$ in male patients and $30.2 \mathrm{UI} / \mathrm{ml}$ in female patients. ${ }^{15}$ There is no explanation for this difference between sexes.

The presence of positive IgE dendritic cells in the skin of $A D$ patients shows that there might be a pathogenic relation between the serum levels of this immunoglobulin and $A D .{ }^{20}$ Since pruritus is the main symptom reported by $A D$ patients, we sought a relation between patients with frequent itching and their IgE levels. There was no statistical significance between the groups of patients, but it was possible to verify that the median serum IgE level was higher in patients suffering from pruritus every day when compared with those with longer symptom intervals. These data enable speculating there might be a correlation between these factors and further studies with larger samples could demonstrate this suspicion.

\section{CONCLUSION}

Analyzing together these data, we concluded that more severe $A D$ patients presented pruritus much more often than those with milder cases. Although serum IgE levels were higher in more severe patients, they were not statistically significant to demonstrate a correlation with severity of clinical manifestations. Male AD patients presented higher serum IgE levels than females.

dermatitis correlate with serum IgE levels? Pediatric Allergy Immunol. 2004;15:86-8.

14. Brostoff J, Hall T. Hipersensibilidade - Tipo I. In: Roit I, Brostoff J, Male D. Imunologia. São Paulo: Editora Manoele; 1997.

15. Spalding SM, Wald V, Bern LAG. IgE sérica total em atópicos e não-atópicos na cidade de Porto Alegre. Rev Assoc Med Brasil. 2000;46:93-7.

16. Klein P, Clark RAF. An Evidence-Based Review of the Efficacy of Antihistamines in Relieving Pruritus in atopic dermatitis. Arch Dermatol. 1999;135:1522-5.

17. Emerson A, Williams HC, Allen BR. How much disability does atopic eczema cause compared with other common childhood health problems? Br J Dermatol. 1997; 137:19.

18. Yosipovitch G, Goon JTA, Wee J, Chan YH, Zucker I, Goh $\mathrm{CL}$. Itch characteristics in Chinese patients with atopic dermatitis using a new questionnaire for the assessment of pruritus. Int J Dermatol. 2002;41:212-6.

19. Costa C, Rilliet A, Nicolet M, Saurat JH. Scoring atopic dermatitis: the simpler the better? Acta Derm Venereol. 1989; 69:41-5.

20. Rajka G, Langelang T. Grading the severity of atopic dermatitis. Acta Derm Venereol. 1989; 144:13-4.

21. Stalder JF, Taieh A. Severity scoring of atopic dermatitis, the SCORAD index. Consensus report of the European Task Force on atopic dermatitis. Dermatology. 1993; 186:23-31.

\author{
MAILING ADDRESS: \\ Magda Blessmann Weber \\ Av. Neuza G. Brizola, 495\301 \\ Porto Alegre RS $90460-230$ \\ Tel./fax: (51) 3333-4025 \\ E-mail: mbw@terra.com.br
}

